\title{
Studies in Cyanophyceaean Algae from Maize Fields in Solapur
}

\author{
Seema Khadatare, D. S. Suryawanshi \\ ${ }^{1}$ Department of Botany, Jawahar Arts, Science and Commerce College, Andur, Tal.Tuljapur, Dist. Osmanabad
}

\begin{abstract}
The ecological value of soil algae is very important as they contribute to soil formation, fertigation of nutrients. Blue-green algae make a major contribution to the fertility of the soil. It has been suggested that blue-green algae (BGA) assist higher plant growth by supplying vital nutrients. There are numerous works about roles of blue-green algae on growth of maize fields. Increase in use of synthetic fertilizers in the field badly affected the fertility of the soil. These synthetic fertilizers are effecting on flora and fauna of the field responsible for productivity of the crop plants. Most of the farmers are utilizing these fertilizers blindly to increase productivity. To check proper dosage and relative abundance of the blue green algae efforts were made to evaluate abundance of blue green algae from Mohol tehsil of Solapur district. During the investigations, 19 species of blue green algae belonging to three families of heterocystous and non-heterocystous from maize fields in Mohol Tahasil of solapur district were identified, out of which seven species are new to this region.
\end{abstract}

Keywords: Blue green Algae, biofertilizer, Cyanophyta, Solapur

\section{Introduction}

Blue green algae i.e. Cyanobacteria represent a small taxonomic group of photosynthetic prokaryotes which some of them are able to N2 fixation and also possess a tremendous potential for producing a wide range of secondary metabolites. Cyanobacteria have drawn much attention as prospective and rich sources of biologically active constituents and have been identified as one of the most promising groups of organisms capable of producing bioactive compounds (Fish \& Codd 1994, Schlegel et al.1999). Production of bioactive molecules such as auxins, production of secondary metabolites linked to bio control of bacterial and fungal diseases as well as improving oil structure and porosity through secretion of polysaccharides aiding in soil aggregation are the most important functions of these microorganisms (Karthikeyan et al. 2007, Sergeevaet al. 2002).

De (1939) attributed the natural fertility of maize fields oil and its maintenance to the process of biological nitrogen fixation by cyanobacteria. This was the first report, which recognized the agronomic potential of cyanobacteria in India. The widespread application of single element fertilizers (especially $\mathrm{N}$ in Asian countries) in the cultivation of major crops has led to accelerated exhaustion of other major and minor nutrients leading to nutrient imbalances and poor soil fertility. In the current scenario therefore, an urgent need has been felt to deploy microbial bio-fertilizer which are multifaceted such as cyanobacterial biofertilizer. As yet for substitution of chemical fertilizers by microbial bio fertilizers many studies have been done. Gupta \& Shukla (1967) studied the algal influence on growth, yield and protein content of maize plants and showed thatpre-soaking maize seeds with BGA cultures or extracts enhances germination, promotes the growth of roots and shoots, and increases the weight and protein content of the grain. Svircevet al. (1997) also reported that plant growth was enhanced in the presence of cyanobacterium, even without organic $\mathrm{N}$ fertilizer application. Beneficial effects of cyanobacterial inoculation were reported, not only for maize, but for other crops such as wheat, soybean, oat, tomato, radish, cotton, sugarcane, chili, bean, muskmelon and lettuce (Venkataraman 1972, Rodgerset al. 1979, Singh 1988, Arifet al. 1995, Thajuddin \& Subramanian 2005, Saadatnia \& Riahi 2009, Maqubelaet al. 2008, Karthikeyan et al. 2007). Several reasons have been proposed for beneficial effects of cyanobacteria on the growth of different plants. The capacity for biosynthesis of growth promoting substances such as auxins, amino acids, sugars and vitamins(Vitamin B12, Folic acid, Nicotinic acid and Pantothenicacid ) was reported by Misra \& Kaushik (1989 a, b) that can enhance growth of plant.

Additionally, cyanobacteria excrete complex organic carbon compounds that bind to the soil particles and improve soil aggregation, hence improve soil structure, soil permeability and water holding capacity of soil (Kaushik 2007). However, to date, the effect of single species cyanobacteria biofertilizer on plant growth has not yet been fully investigated. The primary aim of this research was to study cyanobacteria species isolated from soil. There are numerous works about roles of blue-green algae on growth of maize fields. Increase in use of synthetic fertilizers in the field badly affected the fertility of the soil. These synthetic fertilizers are effecting on flora and fauna of the field responsible for productivity of the crop plants. Most of the farmers are utilizing these fertilizers blindly to increase productivity. To check proper dosage and relative abundance of the blue green algae efforts were made to evaluate abundance of blue green algae from Mohol tehsil of Solapur district.

\section{Materials and Methods}

Soil samples were collected from the depth of $0-5 \mathrm{~cm}$ on severalmaize fields in Moholtahasil of Solapur district of Maharashtra.(Rangaswamy 1996).

\section{Isolation of cyanobacteria}

Soil samples were transferred to sterile Petridishes and added to them sterilized BG-11 medium with $\mathrm{pH}$ : 7.1. The Petri dishes were placed in a culture chamber at $25^{\circ} \mathrm{C}$ and a $12 / 12$ 


\section{International Journal of Science and Research (IJSR) \\ ISSN (Online): 2319-7064 \\ Index Copernicus Value (2015): 78.96 | Impact Factor (2015): 6.391}

$\mathrm{h}$ light dark cycle at artificial illumination (2000-2500 Lux) for two weeks. After colonization, for purification, identification and multiplication of colonies, a part of each colony was removed by a loop and transferred to a new plate. After purification of taxa, taxonomic determination was carried out by light microscopy and based on Desikachary (1959), Prescott (1970) and Wehret al.
(2002), and corrected based on algae base website(www.algaebase.org). 3. Results In the present study, seven taxa of heterocystous and 12 taxa of non-heterocystous cyanophyta were identified. Nostocaceae with four genera and seven species, Oscillatoriaceae with three genera and six species and Chroococcaceae with four genera and six species were included in the list of isolates (Table 1).

Table 1: Total percent abundance of cyanobacteria genera (summed up over all locations)

\begin{tabular}{|l|l|l|l|l|l|l|}
\hline Genus & \multicolumn{2}{|c|}{ Localities in Mohol Tahasil } & Total No. of species & Percent abundance \\
\hline & Anagar & Aasti & Penar & Kamati & & \\
\hline Anabaena & + & + & + & + & 2 & 5.2 \\
\hline Aphanothece & + & + & + & + & 1 & 5.2 \\
\hline Chroococcus & + & + & + & + & 3 & 16 \\
\hline Cylindrospermum & - & - & + & + & 1 & 5.2 \\
\hline Gleocapsa & + & - & + & + & 2 & 5.2 \\
\hline Gloeothece & + & + & - & - & 1 & 5.2 \\
\hline Lyngbya & + & + & + & + & 1 & 5.2 \\
\hline Nodularia & + & + & + & + & 2 & 5.2 \\
\hline Nostoc & + & + & + & + & 4 & 21 \\
\hline Oscillatoria & + & + & - & + & 2 & 10.6 \\
\hline Phormidium & - & - & - & - & 3 & 16 \\
\hline & & & & Total & 22 & 100 \\
\hline
\end{tabular}

Abundance of these species was studied of these species. It was observed that Nostocwas most abundant with $25 \%$ occurance followed by Phromidium and Chroococus up to 16 percentage followed by Oscillatoria with $10.6 \%$. This was followed by Anabaena, Cylendrospermum, Nodularia, Aphanotheca, Gloeotheca and Gloeocapsa with $5.2 \%$.

\section{Conclusion}

From the studies it could be revealed that, Nostoc is the dominating blue green algae plays its role in productivity of maize crop. Promidium and Chroococcus are the second largest species play their vital role productivity of crops and are the second largest group of blue green algae. If dose of synthetic utilized properly, they may nurture are favorable for the growth of blue green algae. This will lead to fertility of soil and will definitely effect on productivity of crop plants such as Maize.

\section{Acknowledgement}

Authors are thankful to Principal, Jawahar Arts, Science and Commerce College, Andur, Tal. Tuljapur, Dist. Osmanabad for providing laboratory facilities to carry out the research work.

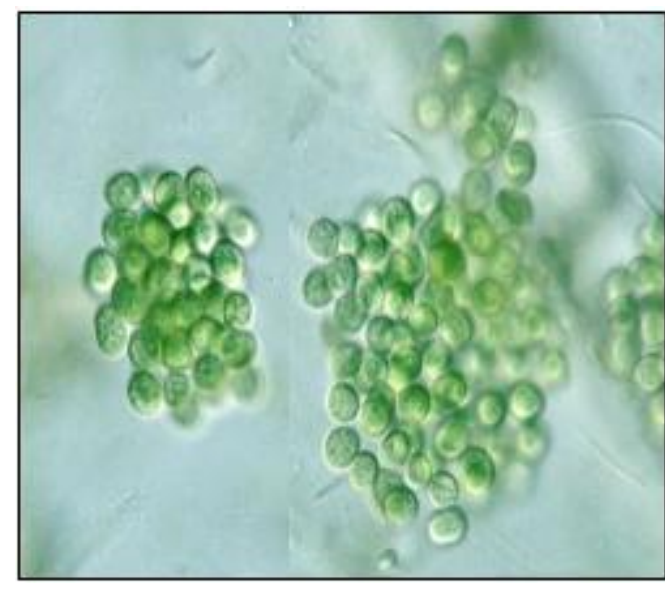

Figure: Aphanotheca sp

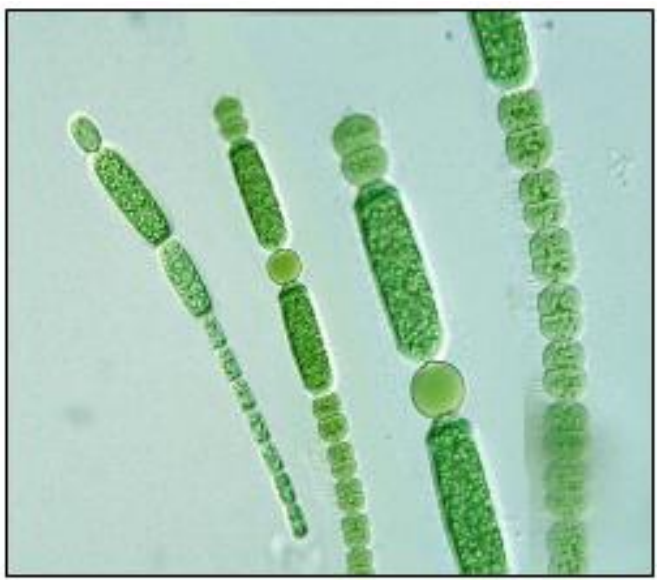

Figure: Cylindrospermum sp 


\section{International Journal of Science and Research (IJSR) \\ ISSN (Online): 2319-7064}

Index Copernicus Value (2015): 78.96 | Impact Factor (2015): 6.391

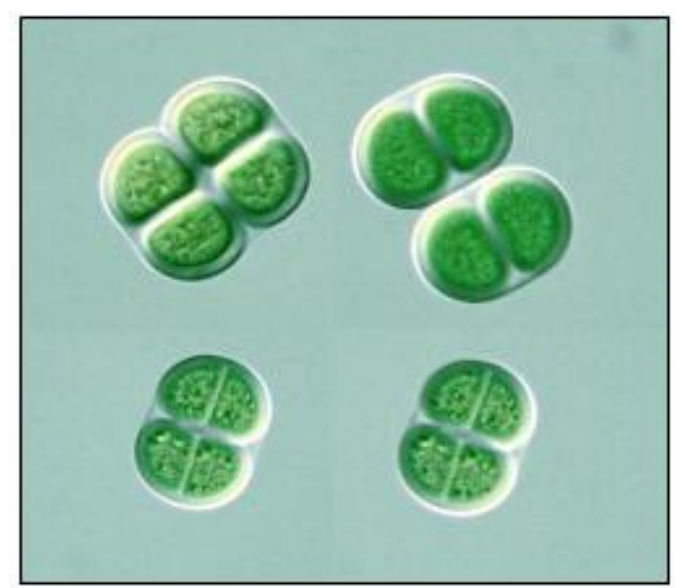

Figure: Gloeotheca sp

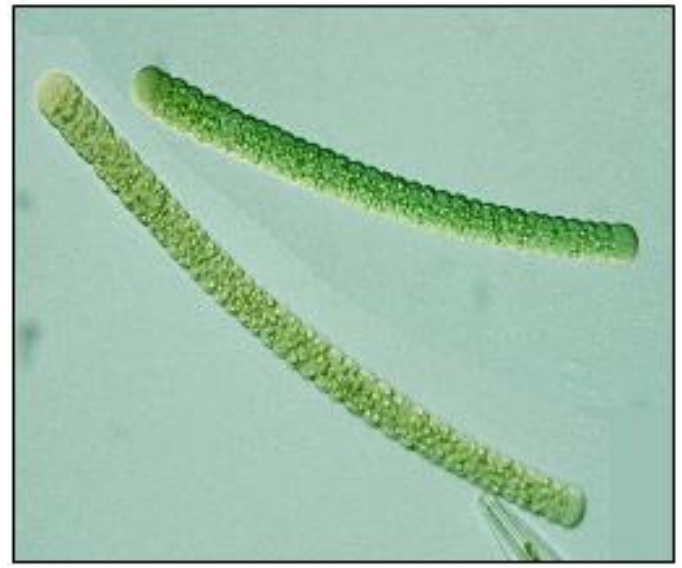

Figure: Nodularia sp.

\section{References}

[1] Desikachary, T.V. 1959. Cyanophyta. New Delhi: Indian Council of Agricultural Research. 686 pp.

[2] De, P.K. 1939. The role of blue-green algae in nitrogen fixation in rice fields. Proceeding of the Royal Society of London. Series B 127: 121-139.

[3] Fish, S.A. \&Codd, G.A. 1994. Bioactive compound production by thermophilic and thermo tolerant cyanobacteria (blue-green algae). World Journal of Microbiology and Biotechnology 10:338-347.

[4] Karthikeyan, N., Prasanna, R., Nain, L. \& Kaushik, B.D.2007. Evaluation of the potential of plant growth promoting cyanobacteria as inoculants for wheat fields. European Journal of Soil Biology 43: 23-30.

[5] Kaushik, B.D. 2007. Cyanobacterial biofertilizer technology. Pp. 53-59. In: S. Kannaiyan, K. Kumar \& K. Govindarajan (eds). Biofertilizers technology. Scientific Publishers. India.

[6] Maqubela, M.P., Mnkeni, P.N.S., Malamissa, O.,Pardo, M.T. \&Acqui, L.P.D. 2008. Nostoc cyanobacterial inoculation in South African agricultural soils enhances soil structure, fertility and maize growth. Plant and Soil 315: 79-92.

[7] Misra, S. \&Kaushik, B.D. 1989a. Growth promoting substances of cyanobacteria I. Vitamins and their influence on rice plant. Proceeding of the Indian Science Academy B55: 295-300.

[8] Misra, S. \& Kaushik, B.D. 1989b. Growth promoting substances of cyanobacteria II. Detection of amino acids, sugars and auxins. Proceeding ofthe Indian Science Academy B55: 499-504.

[9] Prescott, G.W. 1970. Algae of the western great lake sarea. WM. C. Brown Company Publishers.977 pp.

[10] Rangaswamy, G. 1996. Agricultural microbiology. Asia Publishing House, Bombay, p.54-76.

[11] Saadatnia, H. \&Riahi, H. 2009. Cyanobacteria from paddy-fields in Iran as a biofertilizer in riceplants. Plant Soil Environment 55(5): 207-212.

[12] Schlegel, I., Doan, N.T., De Chazol, N. \&Smit, G.D.1999. Antibiotic activity of new cyanobacterial isolates from Australia and Asia against green algae and cyanobacteria. Journal of Applied Phycology 10: 471479.

[13] Sergeeva, E., Liaimer, A. \& Bergman, B. 2002. Evidence for production of the phytohormone indole-3acetic acid by cyanobacteria. Planta215: 229-238. 